\title{
Communicative Language Teaching (CLT): A Critical and Comparative Perspective
}

\author{
Fang-an Ju \\ China Renmin University Press, 31 Zhongguancun Street, Beijing, 100080, China
}

\begin{abstract}
Communicative Language Teaching (CLT) came up at the beginning of the nineteenth century, and formalized in the late $1960 \mathrm{~s}$, reflecting the social changes. It is critically evaluated as a theory in foreign language teaching based on an overall review of its history, theory and application. However, the difficulties of its application in certain countries are continually discussed, such as cultural conflicts and teacher training. Based on the evaluation, this essay points out that only combined with the characters like teaching environment, educational background and cultural background of teachers and learners, as well as test systems will CLT play a more significant role in language teaching.
\end{abstract}

Index Terms — critical evaluation, CLT, SLT, language teaching, cultural background, test systems, challenges

\section{PURPOSE OF THIS ESSAY}

Communicative Language Teaching (CLT), rooted in the multidiscipline, the initiation of communicative approach, which is regarded as a revolution, impinges on the outmoded teaching schema and the newcomers of disciplines, such as psycholinguistics and sociolinguistics, is an innovative language teaching approach formed in the late 1960s, when pragmaticism prevailed much more than ever in the West, and when the post World-War II world called much more dialogue and communications. CLT has greatly influenced language teaching both theoretically and practically. The past half century has witnessed many scholars around the world discussing, reviewing and improving the approach, with many textbooks, syllabus designed based on it. Many teachers and learners came to know this theory and benefited from it. It cannot be denied that CLT has made a significant contribution to foreign language teaching, though it does consist of some shortcomings that are innate in the formulation of the theory or in the application. In this essay, based on a brief review of its history, theory and application, and compared with Situational Language Teaching (SLT), I will critically evaluate CLT as a theory as well as its practice in foreign language teaching.

\section{Why Communicative Language Teaching (CLT): A Comparative Perspective between Communicative Language Teaching (CLT) AND Situational Language TEAChing (SLT)}

Communicative Language Teaching (CLT) appeared in the 1960s when language studies and foreign language teaching ideas made big changes in America, Britain and Europe. Before that, Situational Language Teaching (SLT) had dominated foreign language teaching in Britain for many years as a conventional language teaching approach. However, in the mid-1960s, linguists in the United States, based on Chomsky's view of the language acquisition device and linguistic competence, began to critically review SLT and even rejected Audiolingualism (AL), an approach which is based on behaviorist psychology and structural linguistics that focuses on "the drilling, the formation of habit and the avoidance of error" (Klapper, 2006, P.107). This change made British linguists aware of the imperfection of SLT and they began to question its theoretical assumptions. "They saw the need to focus in language teaching on communicative proficiency rather than language" (Richards and Rodgers, 2001, P.153). Scholars like Candlin, Widdowson, and Wilkins put forward communicative analysis to foreign language teaching and the syllabus design. Another impetus "came from the changing educational realities in Europe" (Richards and Rodgers, 2001, P.154). The need to teach more adults the major languages for the European Common Market communication called for a more effective foreign language teaching approach. Therefore, Chomsky's view of linguistic competence, the writings of British linguistics and the work of the European Council brought about the advent of Communicative Language Teaching and expanded it to a larger scale (Richards and Rodgers, 2001, P.154-155).

The theory of the communicative approach has been influenced by many disciplines like sociolinguistics, psycholinguistics, language philosophy, anthropology, among which the most influential factor is sociolinguistics. As Fishman says, the task of sociolinguistics is to study "who speaks what language to whom and where" (cited in Hu, 1982, P.15). Moreover, Hymes (1971 cited in Richards and Rodgers, 2001, P.159) coined the term "Communicative Competence" in order to "contrast a communicative view of language and Chomsky's theory of competence". In Chomsky's view, linguistic theory studies are only concerned about abstract language in a vacuum, the perfect language which is not affected by actual practice in the society. But Hymes holds the view that "a learner's need to focus on appropriate use, which is on using language for particular purposes and in particular situations and settings" (Klapper, 2006, P.109). This notion has been specified by Canale and Swain's "four dimensions of communicative competence", 
namely, "grammatical competence, sociolingual competence, discourse competence and strategic competence" (1980 cited in Klapper, 2006, P.109) and later extended in turn by Bachman, Celce-Murcia, Dornyei, and Thurrell (1997 cited in Richards and Rodgers, 2001, P.160).

According to this theory, the aim of language learning is to acquire communicative competence, or the four dimensions of competence. Some principles have been proposed by Richards and Rodgers (2001, P.161) with regard to language learning:

"Communication principle: Activities that involve real communication promote learning...task principle: Activities in which language is used for carrying out meaningful tasks promote learning...meaningfulness principle: Language that is meaningful to the learner supports the learning process."

Consequently, language learning activities are supposed to be developed and fulfilled around these principles. The "desired outcome", as Knight (2001, P.155) states, "is that the learner can communicate successfully in the target language in real situations, rather than have a conscious understanding of the rules governing that language."

The aims and principles of CLT alternate the content, strategies and methods of language teaching and learning, and also change the roles of language teachers as well as learners. Compared with its previous approaches, CLT has greatly reformed language teaching and made a huge contribution to the language learners, but in its application the problems also occur.

Different from the traditional SLT approach, the aim of CLT emphasizes language learners' "communicative proficiency" rather than "a mere mastery of grammar and structures" (Richards and Rodgers, 2001, P.161), which caters to the learner's actual communicative needs and thus allows more efficient interaction for learners. Learners do not learn the language for the purpose of acquiring the grammars and vocabularies per se; rather, they use the language to communicate with others or to comprehend the information others send to them (Richards and Rodgers, 2001, P.160). Moreover, with a clear instrumental purpose, learners tend to have a stronger motivation for learning language.

With regard to syllabus design, "the first element", according to Klapper's (2006, P.109) view, "ought to be a consideration of what learners are likely to have to do in the language, of their needs, expressed in terms of function (e.g. thinking, expressing sadness) and notions (e.g. time), onto which should then be mapped the expressions, vocabulary and grammar required to articulate them". Here needs analysis is regarded as the primary step in CLT course design. It may be a professional need to pursue a better performance in the career, or a social need to travel in another country, or even a relaxation need to have some fun in the process of learning. Generally speaking, most learners have at least one or two kinds of motivation to learn a language. But how about a child or a teenager in the school who has no interest in language learning and is reluctant to learn it? What can teachers do to assess these learners' needs and work out a syllabus for them? In this sense, the drawbacks of CLT are most obvious when specific interaction in a certain field is required.

With regard to the content or the materials of language learning, CLT stresses real and authentic materials that cater to learners' real communicative needs. CLT practitioners believe that materials play "a primary role of promoting communicative use" (Richards and Rodgers, 2001, P.168). They limit the use of conventional grammatical drilling exercises and add other means such as role play, cue cards, activity cards, and other audio or visual forms to practice learner's interactive competence. Three kinds of materials have been commonly used, namely, "text-based materials, task-based materials and realia" (Richards and Rodgers, 2001, P.169-170). Various kinds of materials provide learners the resources they may encounter in real communication in a vivid way, which also bring interests to the class. It is superior to SLT that learners are taught how to appropriately interact in real situations and settings, instead of being taught how to correctly use grammatical structures. But through this way and under this settings and situations, learners are not likely to get a comprehensive and systematic mastery of all grammars that they may require since all the situations and settings cannot be covered in a systematic way. This problem lay on the notion of "competence" in the CLT theory itself. It is still a question whether the notions of extended competences can be all covered or not. Moreover, CLT practitioners all agree that learners should be taught with grammatical rules, and what is more, they should be taught with rules of speaking (Hu, 1982, P.20). But it has no certain answers for what are the rules of speaking and whether all the rules of speaking can be listed.

The insufficient and unsystematic learning of grammar may result in inaccurate expressions, which brings about another issue concerning language learning: fluency and accuracy. CLT focuses on fluent interaction with others, even at the expense of accuracy. Errors are tolerable since they do not interfere with the successful transformation of information. This focus met the original British and European teaching requirements, because the language learners at that time were mainly for the purpose of studying, working or living abroad. To be able to interact with native speakers successfully was their primary purpose of learning a language. However, this theory does not meet with all the language learners' needs. For example, in China, there is a large number of English learners (as L2) who expect that they will be able to publish academic articles in international journals (needless to say, most of them are English version). They do not care much about their speaking ability because most of them have little chance to communicate with native speakers face to face. For those people, writing accurately in English, instead of "writing fluently", is their language need. Obviously, how to cater to this group of learners is a big challenge for CLT practitioners since they do not care much about accuracy of language.

Another aspect closely relates to syllabus design is the roles of learners and teachers. The emphasis of 
communication in CLT theory calls for the maximum presentation of learners and the minimum appearance of teachers. On the one hand, learners' role, as illustrated by Breen and Candlin (1980 cited in Richards and Rodgers, 2001, P.166), is like this:

"Negotiator-between the self, the learning process, and the object of learning-emerges from and interacts with the role of joint negotiator within the group and within the classroom procedures and activities which the group undertakes. The implication for the learner is that he should contribute as much as he gains, and thereby learn in an interdependent way."

On the other hand, Breen and Candlin (1980:99 cited in Richards and Rodgers, 2001, P.167) give a very detailed description of a teacher's roles:

"The teacher has two main roles: the first role is to facilitate the communication process between all participants in the classroom, and between these participants and the various activities and texts. The second role is to act as an independent participant within the learning-teaching group... These roles imply a set of secondary roles for the teacher; first, as an organizer of resources and as a resource himself, second as a guide within the classroom procedure and activities...A third role for the teacher is that of researcher and learner, with much to contribute in terms of appropriate knowledge and abilities, actual and observed experience of the nature of learning and organizational capacities."

With CLT, learners are placed in the communicative settings and acquire language knowledge and communicative competence through active participation and interaction; while teachers change from a knowledge-giver to an organizer, facilitator and researcher. Sometimes teachers turn into a participant in the class activities. In other words, teachers stand back like an observer and manager to stimulate and direct successful communication by means of role plays, games, presentations and so on, whereas learners are put in the center of the class to participate in various kinds of communicative activities. By completing these activities, learners get a huge amount of chances to practice and produce their language, and thus their motivation will be increased and enlarged and their fluency will be improved. Meanwhile, they can learn from hearing other members' presentations (Richards, 2006, P.20). The learner-centered class has been proved to be very beneficial in language teaching. What is more, the replacement broke the traditional authentic role of teachers and gives a new vision for language teachers to rethink about their roles. This influence is even greater in these countries like China and India where the traditional image of teachers is respectful, authoritative, and superior. CLT offers the chance for the teachers to put off the dress of God and get involved with learners in a more friendly way.

However, the application of CLT also encounters difficulties in these countries. Theoretically speaking, needs analysis should be undertaken by the language teacher in a detailed way and individualized direction is recommended to offer to the students. However, because of the large population, English teaching in China always takes the form of big classes with more students. The number of students in English classes is generally over 30, and in many cases, the number rises to over 50, sometimes even more than a hundred. It is almost impossible for English teachers to analyze each learner's need and put forward an effective instruction which correspond to all learners' needs. Even if the teacher can deal with all the needs, how can he or she work out a plan which is suitable for such a large group of students who certainly have a variety of needs in the aspects of level and category? Besides, such a large number of students are not easy to take individual activities in class because of the limit of time in class. The most possible solution for the teacher may be a compromising way to cater for most students as a group.

Apart from these, the cultural conflicts embraced in the CLT approach do affect its application to some extent, role changes, for example. The advocacy of individualism in the student role shows the disagreement with the oriental value of collectivism, and the democracy and equality between teachers and students also destroys the values of authority and distance in education in China. As a result, educators have many controversies and arguments in carrying out the CLT in China and up to now no satisfactory models have been put forward to compromise all the disagreements in value.

Teacher training is another big problem in the countries where real information exchange and authentic communications situation are insufficient. The lack of communication in a real situation with foreigners causes problems for both teachers and learners. Theoretically, CLT emphasizes communicative competence and encourages the fulfillment of successful interaction in dealing with real tasks. The idealist teachers of CLT should be fully competent in language competence, and a good command of the knowledge of linguistics and teaching methodologies. But practically, foreign language users, both teachers and learners, in these countries are unable to receive enough input of communicative practices since they have little chance to meet with native speakers. This kind of language environment is by no means good for the sustainable development of foreign language teaching and learning in these countries. For teachers, the lack of real communication situations makes it more difficult for them to be native-like and their language quality is hard to depend on. For the mass learners, on the other hand, since their communicative needs are not so strong and many of them do not have the specific or urgent requirements to live or work in a foreign country, their motivation to "communicate" in a foreign language is not strong at all and their practice and language abilities in class is difficult to test in real situations. Therefore, how to effectively carry out the CLT approach is really not an easy task in the countries with insufficient foreign language-speaking environment and situations.

Furthermore, there also exists the issue of how to assess teaching results, namely, how to present the result of CLT effectively in different assessment and language tests in different countries. The learners trained by CLT usually have a good performance in their actual work and communication because they have a relatively high communicative proficiency. But their test ability and scores, say in TOEEL or IELTS, may not be higher than other learners trained by 
other approaches. The reason for this is that the aims of the training are different. In some countries, CLT learners still need to find other ways to strengthen their test ability, hoping they can get a more satisfactory score in a certain exam.

To take a deeper study on the application of CLT enables us to find that some controversies and the problems may result from the "lacks of closely prescribed classroom techniques ....and there is no easily recognizable pedagogical framework, no single agreed version of CLT" (Klapper, 2006, P.109). That is why CLT has been adjusted and amended again and again and there are many versions and distortions in the past 50 years.

\section{Challenges AND Changes: CLT in the Future}

(1) Different learning purposes decide different learning methods and no one specific method are suitable for a specific learner.

When talking about CLT or SLT, researchers and scholars sometimes (or usually) fail to decide and determine the purpose of a learner as why he or she learns a foreign language, and even neglect a language-learner's cultural-national background. Definitely, different learning purpose decides different learning methods and no one specific method are suitable for a specific learner. Moreover, people with various cultural-national background may call for different learning methods. Generally speaking, the purposes of people's learning a foreign language could be classified into two types: first, learning a foreign language is for daily use, which could be termed as a communicative-oriented purpose; second, learning a foreign language is for academic use (For example, for future study and research in the field of literature, linguistics, translation and interpretation, etc.), which could be termed as an academic-oriented purpose. Obviously, for people with a communicative-oriented purpose, most probably it is more efficient to adopt the CLT strategy, and they(including learners and teachers) may not pay much attention to the strict grammar rules as well as sentence structures. That is, no matter what grammar errors or pronunciation errors or sentence errors the speaker makes, only on condition that he makes himself understood, all that is ok. We can easily find enough evidence in children who learn a foreign language. When boys and girls learning a foreign language are put under the foreign language-speaking situations where people are all native speakers, they come to learn to speak and talk and could use the language much quickly with no much notice of the grammar rules and sentence structures. For people with an academic-oriented purpose, perhaps it is much more necessary to adopt both the CLT and SLT strategy. Because, CLT emphasizes language learners' communicative competence, while SLT stresses language learners' academic ability of using the language accurately, precisely, properly, gentlemanly and scholarly. In this sense, CLT and SLT is definitely not contradictory to each other, actually they are applied in language teaching and learning side by side, sometimes consciously, sometimes unconsciously to learners and teachers. In another word, CLT and SLT must co-exist to develop in the future so as to facilitate language learners.

(2) New technologies facilitate CLT and SLT or not?

Technologies and new inventions as well as new instruments are pushing human societies forward dramatically and quickly, and it is also the case in the field of language study and learning. In recent years, with the fast development of the Internet technologies, language teaching and learning is undergoing a brand-new reform, which differs dramatically from the traditional language teaching and learning styles: textbooks, additional teaching materials and study strategies are so delicately designed and put into the web, by the means of computers, teachers (educators) can freely arrange, manipulate, direct and assess learning results of the learners, they even do not need go to classes so often than before. That is why nowadays in many universities of China, and also in many middle-schools, much of foreign language teaching is undertaken by the means of computer-aided contents, especially for the listening and speaking lessons. Computer-aided language teaching and learning (namely, E-learning) has made it unnecessary for teachers to go to the class personally. To some extent, whether CLT or SLT, they could be practiced and evaluated by the means of computers. Language learners could easily and freely communicate with a computer to learn a foreign language, anytime and anywhere. Compared with the traditional language teaching and learning, Computer-aided language teaching and learning is both a big challenge and also a benefit to educators, as well as to CLT and SLT. On the one hand, computer-aided language teaching and learning greatly alleviate educators' labor, greatly save educators' energy. Much of the learners' work and exercises, as well as educators' check-up could be finished through computers, face-to-face communications between educators and learners is much reduced. In this sense, computer-aided language teaching greatly freed educators. On the other hand, we face the problem of whether computer-aided language teaching could replace educators in part or in whole. Meanwhile, under computer-aided language teaching circumstances, could CLT and SLT achieve a better result? Are the two methods more welcome to educators or learners than before? All these call for further study, and the answers may be vary for different study target (for example, children, adults, middle school students and college students, as well as learners' cultural-national background should also be taken into consideration. Learners from different countries may also have various attitude towards CLT and SLT, study and research in this regard definitely will not be the same, thus will be of special value.) To sum up, research about CLT and SLT under computer-aided teaching and learning circumstance may be of much significance to language researchers, as well as language linguists. It could be estimated that in the near future more textbooks and syllabus will be designed and carried out in accordance with the computer-aided teaching and learning styles.

\section{CONCLUSION}


Language teaching and language learning is an endless process, just the same as the development of Communicative Language Teaching. With its unique focus and perspective, CLT is still "fashionable" in language teaching and learning field, as can be seen in the updating research and adjustment of CLT linguists and educators, and in the large amount of course designs and textbooks in this regard. Moreover, CLT brings rethinking to language learning and teaching, which has influenced other later linguistic approaches and teaching methodologies. On the other hand, it is impossible to find a perfect approach or methodology which can cater for all learners and be applicable in all situations. All of them need to be continuously adjusted and enriched in real teaching practice situations, and the same is true to CLT. Only combined with the characteristics like teaching environment, educational background and cultural background of teachers and learners, as well as test systems will CLT play a more significant role in language teaching. Whether CLT or SLT, they are all approaches for language learning, and maybe it is more effective to combine both to achieve a more ideal language-learning result, and only taking all new factors such as computer-aided teaching and learning into consideration, could CLT keep vitality and extend influence continuously.

\section{REFERENCES}

[1] Hu, W.Z. (1982). A Tentative Study on CLT. Journal of Foreign Languages (5), 15-22. http://dlib.cnki.net/kns50/detial.aspx?QueryID=3\&CurRec=71 (accessed 25/10/2011).

[2] Klapper, J. (2006). Understanding and developing good practice language teaching in higher education. London: CILT.

[3] Knight, P. (2001). English language teaching in its social context. Abingdon: Routledge.

[4] Richards, J.C. (2006). Communicative Language Teaching Today. New York: Cambridge University Press.

[5] Richards, J.C. and Rogers T.S. (2001). Approaches and Methods in Language Teaching. New York: Cambridge University Press.

Fang-an Ju was born in Shandong Province, China in 1966. He received his bachelor's degree in English language and linguistics from Shandong Teachers' University, China in 1984, and he received his doctor's degree in history from Renmin University of China in 2000. He is currently a senior editor and Director of Foreign Languages Publishing Branch of China Renmin University Press, China. His research interests include English teaching, translation and interpretation, linguistics, as well as history. 